\title{
ANALISIS PENGARUH KEPUASAN KERJA TERHADAP KINERJA KARYAWAN BAGIAN MANAJEMEN DI RSUD BHAKTI DHARMA HUSADA SURABAYA
}

\author{
Rindi Mailani*, Muhadi* \\ *Prodi Administrasi Rumah Sakit \\ STIKES Yayasan Rumah Sakit Dr. Soetomo \\ rindimailani@gmail.com
}

\begin{abstract}
ABSTRACK
Resources is one of the critical components in a service at the hospital, then it is proper hospital perform a maintenance mechanism of human resources by taking into account employees' work satisfaction and so on can evaluate the performance of hospital services quality. This study aims to determine the effect of job satisfaction on employee performance management section in General Hospital Bhakti Dharma Husada Surabaya. Based on data from the first PBL students STIKES Foundation Hospital Dr. Soetomo, the Employee Satisfaction Index analysis is based on the vision can be at 59.03\%. This shows that the employee satisfaction index is still below the minimum of 70\%. This study uses a quantitative descriptive analytical research. Data collection methods used questionnaires to 4 rating scale (lichert). This study tried to assess the influence of the independent variable on the dependent variable. Time approach used in this study, cross sectional study design, because the study was done in a certain time period simultaneously to the variables studied. The population which became a source of data in this study as well as sample research that employees of the management of as many as 58 people. These results indicate that the effect of job satisfaction on the performance had a positive and significant correlation to employee performance. Based on the results of five dimensions of job satisfaction that occupational factor: bosses, workers, coworker, promotions and salaries, the promotion factor and superiors Human became the most influential factor on the performance of employees at General Hospital Bhakti Dharma Husada Surabaya.
\end{abstract}

Keywords: Job Satisfaction, Employee Performanc

\begin{abstract}
ABSTRAK
Sumberdaya manusia merupakan salah satu komponen yang sangat menentukan dalam sebuah pelayanan di rumah sakit, maka sudah selayaknya rumah sakit melakukan suatu mekanisme pemeliharaan sumber daya manusia dengan memperhatikan kepuasan kerja karyawannya dan mengevaluasi kinerja agar di dapat pelayanan rumah sakit yang berkualitas. Penelitian ini bertujuan untuk mengetahui pengaruh kepuasan kerja terhadap kinerja karyawan bagian manajemen di RSUD Bhakti Dharma Husada Surabaya. Berdasarkan data PBL I mahasiswa STIKES Yayasan Rumah Sakit Dr. Soetomo Surabaya, pada analisis indek kepuasan karyawan berdasarkan visi di dapat sebesar 59.03\%. Hal tersebut menunjukkan bahwa indek kepuasan karyawan masih di bawah minimal yaitu 70\%. Penelitian ini menggunakan penelitian deskriptif kuantitatif yang bersifat analitik. Metode pengumpulan data yang digunakan menggunakan kuesioner dengan 4 skala penilaian (lichert). Penelitian ini mencoba menilai pengaruh variabel independen terhadap variabel dependen. Pendekatan waktu yang digunakan dalam penelitian ini, yaitu rancangan bangun cross sectional study,
\end{abstract}


karena penelitian dilakukan pada periode waktu tertentu secara bersamaan terhadap variabel yang diteliti. Populasi yang dijadikan sumber data dalam penelitian ini sekaligus dijadikan sampel penelitian yaitu karyawan bagian manajemen sebanyak 58 orang. Hasil penelitian ini menunjukkan bahwa pengaruh kepuasan kerja terhadap kinerja memiliki korelasi yang positif dan signifikan terhadap kinerja karyawan. Berdasarkan hasil penelitian dari 5 dimensi kepuasan kerja yaitu faktor: pekerjaan, atasan, rekan kerja, promosi dan gaji, pada faktor promosi dan atasan menjadi faktor yang paling berpengaruh terhadap kinerja karyawan di RSUD Bhakti Dharma Husada Surabaya.

Kata Kunci: Kepuasan Kerja, Kinerja Karyawan

\section{LATAR BELAKANG}

Pada era MEA (Masyarakat Ekonomi ASEAN) saat ini, setiap rumah sakit dituntut untuk mampu bersaing dengan rumah sakit-rumah sakit lainnya. Rumah sakitdiharapkan mampu menghasilkan pelayanan yang berkualitas dengan harga yang kompetitif. Hal tersebut dapat terwujud apabila rumah sakit memiliki Sumber Daya Manusia yang kompeten dibidangnya. Untuk itu diperlukan manajemen SDM yang efektif agar tujuan organisasi dapat tercapai dengan baik. Salah satu hal yang perlu diperhatikan dalam manajemen SDM adalah kinerja karyawan. Kinerja karyawan yang tinggi tentunya sangat diharapkan oleh setiap rumah sakit karenamendorong berkembangnya rumah sakit. Karyawan yang kinerjanya baik menunjukkan hasil kerja yang tinggi sedangkan karyawan karyawan yang kinerjanya rendah mewujudkan hasil kerja yang rendah. Peningkatan kinerja karyawan secara otomatis meningkatkan performa rumah sakit.

Mangkunegara(2006) "Sehubungan dengan ini, kinerja SDM adalah prestasi kerja atau hasil kerja (output) baik kualitas maupun kuantitas yang dicapai SDM persatuan periode waktu dalam melaksanakan tugas kerjanya, sesuai dengan tanggungjawab yang diberikan kepadanya". Untuk mengetahui hasil pekerjaan atau kinerja karyawan diperlukan evaluasi kinerja. Evaluasi kinerja dapat dipergunakan untuk memperbaiki atau meningkatkan kinerja dari SDM organisasi di masa mendatang. "Menciptakan lingkungan kerja yang kondusif guna mendorong terciptanya sikap dan tindakan yang profesional dalam menyelesaikan pekerjaan sesuai dengan bidang dan tanggung jawabnya. Sumber daya manusia berperan dalam mengolah dan memanfaatkan sumber daya dan material sehingga menjadi produk. Oleh karena itu untuk meningkatkan kinerja, perlu diperhatikan agar sumber daya manusia dapat bekerja secara efisien dan menampilkan kinerja yang bisa memberi sumbangan terhadap produktivitas merupakan masalah mendasar dari berbagai konsep manajemen dan kepemimpinan" Wulan (2011). Oleh karena sumberdaya manusia merupakan salah satu komponen yang sangat menentukan dalam sebuah pelayanan di rumah sakit, maka sudah selayaknya rumah sakit melakukan suatu mekanisme pemeliharaan sumber daya manusia dengan memperhatikan kepuasan kerja karyawannya dan mengevaluasi kinerja agar di dapat pelayanan rumah sakit yang berkualitas.

Tabel 1 Analisis Indek Kepuasan Karyawan Berdasarkan Misi

\begin{tabular}{|l|l|l|c|l|}
\hline \multirow{2}{*}{ No } & \multirow{2}{*}{$\begin{array}{c}\text { Kata Kunci dan } \\
\text { indikator }\end{array}$} & \multicolumn{3}{|c|}{ Indikator } \\
\cline { 3 - 5 } & \multicolumn{2}{|c|}{ IKK } & IKM & NDR \\
\hline 1 & Pelayanan Terbaik \\
\hline a & Mutu Pelayanan & $59,03 \%$ & $85,25 \%$ & $4 / 1000$ \\
\hline b & Kepuasan & 59,67 & $85,25 \%$ & $4,7 \%$ \\
\hline
\end{tabular}

Berdasarkan data PBL I mahasiswa STIKES Dr. Soetomo Surabaya di RSUD Bhakti Dharma Husada Surabaya, pada 
analisis IKK berdasarkan visi didapat sebesar 59, 03\%. Hal tersebut menunjukkan bahwa IKK masih di bawah minimal yaitu $70 \%$. Oleh karena itu peneliti ingin mengetahui lebih lanjut IKK pada bagian manajemen dan pengaruhnya terhadap kinerja karyawannya.

\section{METODE PENELITIAN}

Penelitian ini merupakan penelitian deskriptif kuantitatif. Desain penelitian ini bersifat analitik.Penelitian dilaksanakan pada bulan Juni sampai dengan Juli 2016 dibagian manajemen RSUD Bhakti Dharma Husada Surabaya.Populasi dari penelitian ini adalah karyawan bagian manajemen RSUD Bhakti Dharma Husada. Sampel dari penelitian ini ialah seluruh karyawan bagian manajemen RSUD Bhakti Dharma Husada Surabaya yang berjumlah 48 orang. Metode yang digunakan peneliti ialah sampling jenuh.Instrumen penelitian yang digunakan dalam penelitian ini menggunakan kueisoner.Analisis data yang diperoleh dalam penelitian ini akan dilakukan dengan menggunakan SPSS. Metode analisis data dalam penelitian ini dengan menggunakan regresi linier.

\section{HASIL}

Tabel 2 Karakteristik Responden

\begin{tabular}{|r|l|r|r|}
\hline No & \multicolumn{1}{|c|}{$\begin{array}{c}\text { Karakteristik } \\
\text { responden }\end{array}$} & Jumlah & \multicolumn{2}{|c|}{$\%$} \\
\hline 1 & Umur & 8 & 14 \\
\hline & a. $18-28$ & 38 & 66 \\
\hline & b. $29-39$ & 4 & 7 \\
\hline & c. $40-49$ & 8 & 14 \\
\hline & d. $\geq 50$ & 58 & 100 \\
\hline & Total & \multicolumn{2}{|r|}{} \\
\hline 2 & Jenis Kelamin & 35 & 60 \\
\hline & Perempuan & 23 & 40 \\
\hline & Laki - laki & 58 & 100 \\
\hline & Total & \multicolumn{2}{|r|}{} \\
\hline 3 & Pendididkan & 4 & 7 \\
\hline & SMA/SMK & 4 & 7 \\
\hline & D3 & 46 & 79 \\
\hline & S1 & 4 & 7 \\
\hline & S2
\end{tabular}

\begin{tabular}{|c|c|c|c|}
\hline No & $\begin{array}{c}\text { Karakteristik } \\
\text { responden }\end{array}$ & Jumlah & $\%$ \\
\hline & Total & 58 & 100 \\
\hline 4 & \multicolumn{3}{|l|}{ Lama Bekerja } \\
\hline & $0-4$ tahun & 8 & 14 \\
\hline & $5-8$ tahun & 44 & 76 \\
\hline & $9-11$ tahun & 0 & 0 \\
\hline & $\geq 12$ tahun & 6 & 10 \\
\hline & Total & 58 & 100 \\
\hline \multirow[t]{4}{*}{5} & \multicolumn{3}{|l|}{ Status } \\
\hline & Nikah & 52 & 90 \\
\hline & Belum menikah & 6 & 10 \\
\hline & Total & 58 & 100 \\
\hline \multirow[t]{6}{*}{6} & \multicolumn{3}{|l|}{ Gaji } \\
\hline & $2-3,5$ juta & 41 & 71 \\
\hline & $3,6-4,1$ juta & 9 & 17 \\
\hline & $4,2-4,7$ juta & 4 & 6 \\
\hline & $\geq 4,8$ juta & 4 & 6 \\
\hline & Total & 58 & 100 \\
\hline \multirow[t]{4}{*}{7} & \multicolumn{3}{|c|}{ Penghasilan Tambahan } \\
\hline & ada & 32 & 55 \\
\hline & tidak ada & 26 & 45 \\
\hline & Total & 58 & 100 \\
\hline
\end{tabular}

Karakteristik responden berdasarkan umur menunjukkan bahwa dari 58 responden, sebagian besar yang dominan bekerja pada bagian manajemen berusia 29 sampai dengan 39 tahun yaitu sebanyak 38 orang $(65 \%)$.Karakteristik berdasarkan jenis kelamin menunjukkan bahwa dari 58 responden mayoritas adalah perempuan yaitu sebanyak 35 orang $(60 \%)$ dan 23 orang $(40 \%)$ adalah laki-laki. Karakteristik responden berdasarkan tingkat pendidikan terakhir dapat diketahui bahwa karyawan RSUD Bhakti Dharma Husada Surabaya bagian manajemen tingkat pendidikan terakhir yang paling dominan adalah S1 yaitu sebanyak 46 orang $(79 \%)$.Karakteristik berdasarkan lama bekerja diketahui bahwa sebagian besar karyawan yang dominan lama bekerja pada RSUD Bhakti Dharma Husada Surabaya bagian manajemen adalah mayoritas sudah bekerja selama 5 sampai dengan 8 tahun yaitu 44 orang $(76 \%)$. Karakteristik berdasarkan status sebagian besar karyawan RSUD Bhakti Dharma Husada Surabaya bagian manajemen berstatus sudah menikah yaitu 
sebanyak 52 orang (90\%). Karakteristik responden berdasarkan gaji karyawan bagian manajemen RSUD Bhakti Dharma Husada Surabaya sebagian besar berpenghasilan 2 - 3,5 juta yaitu sebanyak 41 orang $(71 \%)$. Karakteristik responden berdasarkan penghasilan tambahan menunjukkan bahwa dari 58 responden sebagian besar karyawan RSUD Bhakti Dharma Husada Surabaya bagian manajemen mempunyai penghasilan tambahan yaitu sebesar 32 orang (55\%).

Tabel 3 Rekapitulasi Hasil Identifikasi Kepuasan Kerja Terhadap Pekerjaan di RSUD Bhakti Dharma Husada Surabaya Tahun 2016

\begin{tabular}{|c|c|c|c|c|c|c|c|c|c|}
\hline \multirow{2}{*}{ No } & \multirow{2}{*}{ Kepuasan kerja terhadap pekerjaan } & \multicolumn{2}{|c|}{ SS } & \multicolumn{2}{|c|}{$\mathrm{S}$} & \multicolumn{2}{|c|}{ TS } & \multicolumn{2}{|c|}{ STS } \\
\hline & & $\mathrm{n}$ & $\%$ & $\mathrm{n}$ & $\%$ & $\mathrm{n}$ & $\%$ & $\mathrm{n}$ & $\%$ \\
\hline 1 & Pekerjaan sesuai kompetensi & 8 & 13,8 & 41 & 70,7 & 8 & 13,8 & 1 & 1,7 \\
\hline 2 & $\begin{array}{l}\text { Bekerja harus menggunakan lebih } \\
\text { dari satu keahlian untuk } \\
\text { menyelesaikan tugas }\end{array}$ & 13 & 22,4 & 44 & 75,9 & 1 & 1,7 & 0 & 0 \\
\hline 3 & $\begin{array}{l}\text { Sarana dan prasarana ATK sudah } \\
\text { memadai }\end{array}$ & 0 & 0 & 28 & 48,3 & 29 & 50,0 & 1 & 1,7 \\
\hline
\end{tabular}

Berdasarkan Tabel 3 di atas menunjukkan bahwa kepuasan kerja terhadap pekerjaan sesuai kompetensi sebagian besar responden mengemukakan setuju yaitu sebanyak 41 orang $(70.7 \%)$. Berdasarkan kepuasan terhadap lebih dari satu keahlian untuk menyelesaikan tugas sebagian besar mengemukakan setuju sebanyak 44 orang (75.8\%). Dan berdasarkan kepuasan terhadap sarana dan prasarana ATK sebagian besar mengemukakan tidak setuju sebanyak 29 orang $(50.0 \%)$

Tabel 4 Rekapitulasi Hasil Identifikasi Kepuasan Kerja Terhadap Atasan di RSUD Bhakti Dharma Husada Surabaya Tahun 2016

\begin{tabular}{|c|c|c|c|c|c|c|c|c|c|}
\hline \multirow{2}{*}{ No } & \multirow{2}{*}{ Kepuasan kerja terhadap atasan } & \multicolumn{2}{|c|}{ SS } & \multicolumn{2}{|c|}{$\mathrm{S}$} & \multicolumn{2}{|c|}{ TS } & \multicolumn{2}{|c|}{ STS } \\
\hline & & $\mathrm{n}$ & $\%$ & $\mathrm{n}$ & $\%$ & $\mathrm{n}$ & $\%$ & $\mathrm{n}$ & $\%$ \\
\hline 1 & $\begin{array}{l}\text { Kebijakan dan kedisiplinan yang } \\
\text { diberikan oleh atasan }\end{array}$ & 8 & 13,8 & 43 & 74,1 & 7 & 12,1 & 0 & 0 \\
\hline 2 & $\begin{array}{l}\text { Atasan harus bersedia } \\
\text { mendengarkan masalah-masalah } \\
\text { yang berkaitan dengan pekerjaan }\end{array}$ & 27 & 46,6 & 29 & 50,0 & 1 & 1,7 & 1 & 1,7 \\
\hline 3 & $\begin{array}{l}\text { Atasan harus bersedia membantu } \\
\text { jika anda mngalami kesulitan dalam } \\
\text { menyelesaikan tugas }\end{array}$ & 22 & 37,9 & 35 & 60,3 & 0 & 0 & 1 & 1,7 \\
\hline
\end{tabular}

Berdasarkan Tabel 4 di atas kepuasan kerja terhadap atasan, pada kebijakan dan kedisiplinan dari atasan terdapat responden yang menyatakan tidak setuju sebesar 7 orang $(12.1 \%)$ hal tersebut perlu menjadi perhatian karena di bandingkan dengan lainnya frekuensi tersebut lebih dominan. Sedangkan pada atasan mendengarkan masalah yang berkaitan dengan pekerjaan, sebagian besar yaitu 29 orang $(50.0 \%)$ 
menyatakan setuju. Atasan harus bersedia membantu jika mengalami kesulitan dalam menyelesaikan tugas, sebagian besar responden menyatakan setuju yaitu sebanyak 35 orang $(60.3 \%)$.

Tabel 5. Rekapitulasi Hasil Identifikasi Kepuasan Kerja Terhadap Rekan Kerja di RSUD Bhakti Dharma Husada Surabaya Tahun 2016

\begin{tabular}{|c|l|c|c|c|c|c|c|c|c|}
\hline \multirow{2}{*}{ No } & \multicolumn{2}{|c|}{$\begin{array}{l}\text { Kepuasan kerja terhadap } \\
\text { rakan kerja }\end{array}$} & \multicolumn{2}{|c|}{ SS } & \multicolumn{2}{|c|}{ S } & \multicolumn{2}{|c|}{ TS } & \multicolumn{2}{c|}{ STS } \\
\cline { 2 - 10 } & $\mathrm{n}$ & $\%$ & $\mathrm{n}$ & $\%$ & $\mathrm{n}$ & $\%$ & $\mathrm{n}$ & $\%$ \\
\hline 1 & $\begin{array}{l}\text { Rekan kerja saling membantu } \\
\text { dalam mengatasi kesulitan } \\
\text { menyelesaikan tugas } \\
\text { pekerjaan }\end{array}$ & 24 & 41,4 & 33 & 56,9 & 0 & 0 & 1 & 1,7 \\
\hline 2 & $\begin{array}{l}\text { Hubungan \& komunikasi } \\
\text { dengan rekan kerja pada } \\
\text { setiap bagian terjalin dengan } \\
\text { baik }\end{array}$ & 12 & 20,7 & 37 & 63,8 & 9 & 15,5 & 0 & 0 \\
\hline 3 & $\begin{array}{l}\text { Tanggungjawab rekan kerja } \\
\text { terhadap hasil pekerjaannya }\end{array}$ & 5 & 8,6 & 43 & 74,1 & 9 & 15,5 & 1 & 1,7 \\
\hline
\end{tabular}

Berasarkan kepuasan kerja terhadap rekan kerja, pada pernyataan rekan kerja saling membantu dalam mengatasi kesulitan menyelesaikan tugas pekerjaan, sebanyak 33 orang $(56.9 \%)$ menyatakan setuju. Selanjutnya pada hubungan \& komunikasi terjalin dengan baik, sebagian besar responden menyatakan setuju yaitu 37 orang $\quad(63.8 \%)$ Berdasarkan tanggungjawab rekan kerja terhadap hasil pekerjaannya sebagian besar responden menyatakan setuju yaitu sebesar 43 orang $(74.1 \%)$.

Tabel 6. Rekapitulasi Hasil Identifikasi Kepuasan Kerja Terhadap Promosi di RSUD Bhakti Dharma Husada Surabaya Tahun 2016

\begin{tabular}{|c|l|c|c|c|c|c|c|c|c|}
\hline \multirow{2}{*}{ No } & \multicolumn{2}{|c|}{$\begin{array}{c}\text { Kepuasan kerjaterhadap } \\
\text { promosi }\end{array}$} & \multicolumn{2}{|c|}{ SS } & \multicolumn{2}{c|}{$\mathrm{S}$} & \multicolumn{2}{c|}{ TS } & \multicolumn{2}{c|}{ STS } \\
\cline { 2 - 10 } & $\mathrm{n}$ & $\%$ & $\mathrm{n}$ & $\%$ & $\mathrm{n}$ & $\%$ & $\mathrm{n}$ & $\%$ \\
\hline 1 & $\begin{array}{l}\text { Mengembangkan potensi diri } \\
\text { di tempat bekerja sesuai } \\
\text { dengan jabatan }\end{array}$ & 16 & 27,6 & 36 & 62,1 & 5 & 8,6 & 1 & 1,7 \\
\hline 2 & $\begin{array}{l}\text { Jabatan yang sesuai } \\
\text { kompetensi sangatlah penting }\end{array}$ & 17 & 29,3 & 40 & 69,0 & 0 & 0 & 1 & 1,7 \\
\hline 3 & $\begin{array}{l}\text { Prestasi di tempat kerja sangat } \\
\text { memungkinkan untuk } \\
\text { mendapatkan } \\
\text { promosi jabatan peluang } \\
\text { jabatan) }\end{array}$ & 13 & 22,4 & 34 & 58,6 & 9 & 15,5 & 2 & 3,4 \\
\hline
\end{tabular}

Berdasarkan Tabel 6 di atas pada kesempatan mengembangkan potensi diri di tempat kerja sesuai dengan jabatan saat ini dominan responden menyatakan setuju yaitu 36 orang $(62.1 \%)$. Selanjutnya jabatan yang sesuai kompetensi sangatlah penting, 
40 orang $(69.0 \%)$ menyatakan setuju. Prestasi di tempat kerja sangat memungkinkan untuk mendapatkan peluang promosi jabatan sebagian besar responden menyatakan setuju yaitu sebanyak 34 orang $(58.6 \%)$.

Tabel 7. Rekapitulasi Hasil Identifikasi Kepuasan Kerja Terhadap Gaji di RSUD Bhakti Dharma Husada Surabaya Tahun 2016

\begin{tabular}{|c|l|c|c|c|c|c|c|c|c|}
\hline \multirow{2}{*}{ No } & \multicolumn{1}{|c|}{$\begin{array}{l}\text { Kepuasan kerja terhadap } \\
\text { gaji }\end{array}$} & \multicolumn{2}{|c|}{ SS } & \multicolumn{2}{|c|}{ S } & \multicolumn{2}{c|}{ TS } & \multicolumn{2}{c|}{ STS } \\
\cline { 2 - 10 } & $\mathrm{n}$ & $\%$ & $\mathrm{n}$ & $\%$ & $\mathrm{~N}$ & $\%$ & $\mathrm{n}$ & $\%$ \\
\hline 1 & $\begin{array}{l}\text { Gaji yang diterima sudah } \\
\text { sesuai dengan beban kerja }\end{array}$ & 3 & 5,2 & 41 & 70,7 & 11 & 19,0 & 3 & 5,2 \\
\hline 2 & $\begin{array}{l}\text { Insentif dapat } \\
\text { meningkatkan motivasi } \\
\text { kerja }\end{array}$ & 16 & 27,6 & 37 & 63,8 & 4 & 6,9 & 1 & 1,7 \\
\hline 3 & $\begin{array}{l}\text { Gaji sudah cukup untuk } \\
\text { memenuhi kebutuhan } \\
\text { hidup }\end{array}$ & 3 & 5,2 & 37 & 63,8 & 14 & 24,1 & 4 & 6,9 \\
\hline
\end{tabular}

Berdasarkan Tabel 7 di atas dapat diketahui bahwa pada pernyataan gaji sudah cukup untuk memenuhi kebutuhan hidup, responden yang menyatakan tidak setuju berjumlah 14 orang $(24.1 \%)$, jika dibandingkan dengan persentase pernyataan tidak setuju lainnya, hasil persentase ini paling dominan.

Tabel 8. Rekapitulasi Hasil Identifikasi Kinerja Karyawan Bagian Manajemen RSUD Bhakti Dharma Husada Surabaya Tahun 2016

\begin{tabular}{|c|c|c|c|c|c|c|c|c|c|}
\hline \multirow{2}{*}{ No } & \multirow{2}{*}{ Kinerja } & \multicolumn{2}{|c|}{ SS } & \multicolumn{2}{|c|}{$\mathrm{S}$} & \multicolumn{2}{|c|}{$\mathrm{TS}$} & \multicolumn{2}{|c|}{ STS } \\
\hline & & $\mathrm{N}$ & $\%$ & $\mathrm{n}$ & $\%$ & $\mathrm{n}$ & $\%$ & $\mathrm{n}$ & $\%$ \\
\hline 1 & $\begin{array}{l}\text { Hasil pencapaian kerja sesuai } \\
\text { dengan tugas pokok dan fungsi }\end{array}$ & 8 & 13,8 & 45 & 77,6 & 5 & 8,6 & 0 & 0 \\
\hline 2 & $\begin{array}{l}\text { Menyelesaikan pekerjaan } \\
\text { dengan teliti }\end{array}$ & 6 & 10,3 & 45 & 77,6 & 6 & 10,3 & 1 & 1,7 \\
\hline 3 & $\begin{array}{l}\text { Menyelesaikan pekerjaan harus } \\
\text { tercapai sesuai dengan target } \\
\text { yang diberikan atasan }\end{array}$ & 6 & 10,3 & 46 & 79,3 & 5 & 8,6 & 1 & 1,7 \\
\hline 4 & Penentuan target dengan SPM & 6 & 10,3 & 47 & 81,0 & 4 & 6,9 & 1 & 1,7 \\
\hline 5 & $\begin{array}{l}\text { Kehadiran harus } 100 \% \text { per } \\
\text { bulan }\end{array}$ & 13 & 22,4 & 26 & 44,8 & 18 & 31,0 & 1 & 1,7 \\
\hline 6 & $\begin{array}{l}\text { Kerja sama baik antar pegawai } \\
\text { di setiap bagian }\end{array}$ & 21 & 36,2 & 36 & 62,1 & 0 & 0 & 1 & 1,7 \\
\hline 7 & bekerja sama dalam satu tim & 18 & 31,0 & 39 & 67,2 & 0 & 0 & 1 & 1,7 \\
\hline
\end{tabular}

Berdasarkan Tabel 8 di atas dapat dilihat dari kinerja berdasarkan hasil pencapaian kerjasudah sesuai dengan tugas pokok dan fungsi sebagian besar menyatakan setuju 
yaitu 45 orang (77.6\%). Berdasarkan penyelesaian pekerjaan dengan teliti sebagian besar menyatakan setuju yaitu 45 orang (77.6\%). Dilihat dari kinerja berdasarkan penyelesaian pekerjaan tercapai sesuai target sebagian besar menunjukkan setuju yaitu 46 orang (79.3\%).

Dilihat dari kinerja berdasarkan penentuan target disesuaikan dengan SPM sebagian besar menyatakan setuju yaitu 47 orang $(81 \%)$. Kinerja berdasarkan kehadiran $100 \%$ dalam sebulan sebagian besar menunjukkan setuju yaitu sebesar 26 orang $(44,8 \%)$ namun selanjutnya 18 orang $(31,0 \%)$ menyatakan tidak setuju, 13 orang $(22,4 \%)$ menyatakan sangat setuju dan 1 orang $(1,7 \%)$ menyatakan sangat tidak setuju. Kinerja berdasarkan adanya kerjasama sebagian besar menyatakan setuju yaitu sebesar 36 orang $(62.1 \%)$ dan kinerja berdasarkan adanya kerjasama dalam satu tim sebagian besar menyatakan setuju yaitu 39 orang $(67.2 \%)$.

Dapat dilihat dari ke tujuh pernyataan yang perlu menjadi perhatian yaitu pada pernyataan ke 5 karena yang menyatakan tidak setuju lebih banyak dibandingkan dengan lainnya.

\section{PEMBAHASAN}

\section{Karakteristik responden}

Analisis karakteristik penelitian ini meliputi: umur, jenis kelamin, pendidikan, lama bekerja status, gaji dan penghasilan tambahan. Sampel dalam penelitian ini pada awalnya 61 orang namun pada akhirnya hanya 58 sampel yang memenuhi untuk penelitian karena 2 dari responden sedang izin cuti melahirkan dan 1 responden izin sakit.

Berdasarkan hasil penelitian umur responden menunjukkan bahwa dari 58 responden, sebagian besar yang dominan bekerja pada bagian manajemen berusia 29 - 39 tahun. Menurut Depkes RI (2013) menyatakan bahwa usia produktif antara $15-54$ tahun. Sehingga umur responden masih masuk dalam kategori produktif karena memiliki rentang 29 - 39 tahun.

Karakteristik jenis kelamin menunjukkan bahwa mayoritas responden adalah perempuan yaitu sebanyak 35 orang (60\%), sedangkan laki - laki sebanyak 23 orang $(40 \%)$. Berdasarkan pada tingkat pendididikan terakhir dapat di ketahui bahwa karyawan bagian manajemen yang palinng dominan adalah $\mathrm{S} 1$ yaitu sebanyak 46 orang (79\%). Hal tersebut menunjukkan bahwa karakteristik berdasarkan pendidikan terakhir sudah cukup baik.

Berdasarkan lama kerja dari hasil penelitian menunjukkan bahwa mayoritas karyawan bagian manajemen sebagian besar lama kerja selama $5-8$ tahun yaitu sebanyak 44 orang $(76 \%)$. Kondisi ini sekaligus mencerminkan bahwa karyawan bagian manajemen memiliki pegawai yang berpengalaman cukup banyak, karena masa kerja yang cukup lama. Hal tersebut sesuai dengan pendapat (Fahmi, 2013) masa kerja adalah masa kerja pendek dan lama memberi pengaruh pada pengalaman dari seorang karyawan. Semakin lama masa kerja maka pengalaman yang dimiliki semakin matang.

Karakteristik berdasarkan status menunjukkan sebagian besar karyawan bagian manajemen berstatus sudah menikah. Salah satu riset menunjukkan bahwa karyawan yang menikah lebih sedikitabsensinya, mengalami pergantian yang lebih rendah, dan lebih puas denganpekerjaan mereka daripada rekan sekerjanya yang bujangan. Pernikahan memaksakan peningkatan tanggung jawab yang dapat membuat suatu pekerjaanyang tetap menjadi lebih berharga dan penting (Robbins, 2006)

Berdasarkan gaji, hasil dari analisa menunjukkan sebagian besar karyawan bagian manajemen berpenghasilan $2-3.5$ juta sebanyak 41 orang (71\%). Gaji merupakan imbalan yang diberikan perusahaan kepada karyawannya, karena karyawan telah memberikan tenaga dan pikirannya kepada 
perusahaan. Oleh karenanya sebaiknya gaji yang diberikan perusahaan haruslah sesuai dengan ketentuan yang berlaku dan sesuai dengan beban kerja yang diberikan kepada karyawan yang pada akhirnya dapat memberikan kepuasan kepada karyawan. Hal ini sesuai dengan pendapat Menurut Luthans (2006) dalam Wibowo (2008), bahwa dalam pembayaran gaji atau upah, pegawai menginginkan sistem upah dan kebijakan promosi yang adil, tidak meragukan dan sesuai dengan harapan.

Berdasarkan penghasilan tambahan, menunjukkan bahwa dari 58 responden sebagian besar karyawan bagian manajemen mempunyai penghasilan tambahan yaitu sebesar 32 orang (55\%).

\section{Kepuasan Kerja Berdasarkan Pekerjaan Terhadap Kinerja Karyawan Bagian Manajemen RSUD Bhakti Dharma Husada Surabaya Tahun 2016}

Berdasarkan pada analisa hasil uji regresi menunjukkan kepuasan terhadap pekerjaan tidak mempunyai pengaruh yang signifikan yaitu $0,233>0.05$. Meskipun tidak berpengaruh namun berdasarkan frekuensi distribusi perlu menjadi perhatian yaitu pada sarana dan prasarana ATK, karena 50\% karyawan menyatakan bahwa sarana dan prasarana ATK belum memadai.

Menurut Gouzali (2000) menyebutkan bahwa keseluruhan sarana dan prasarana kerja yang ada di sekitar pekerjaan dapat mempengaruhi pelaksanaan pekerjaan. Ketersediaan alat tulis kantor sangatlah berpengaruh terhadap tingkat produktifitas pada karyawan. Oleh karenanya, demi mendapatkan performa yang baik dari para karyawan, hendaknya memenuhi semua kebutuhan ATK karyawan. Tidak semua jabatan karyawan membutuhkan jenis peralatan yang sama. Pastikan dalam pemenuhannya mereka mendapatkan alat yang mereka inginkan sesuai dengan tugas dan jabatan mereka karena hal ini berkaitan dengan efisiensi anggaran belanja ATK kantor.

\section{Kepuasan Kerja Berdasarkan Atasan Terhadap Kinerja Karyawan Bagian Manajemen di RSUD Bhakti Dharma Husada Surabaya Tahun 2016}

Dalam meningkatkan produktifitas kerja karyawan, peranan atasan sangatlah penting. Atasan dalam melaksanaan pembinaan karyawan mutlak diperlukan untuk memberikan motivasi atau dorongan dan semangat kerja kepada setiap karyawan, sehingga produktifitas kerja karyawan dapat ditingkatkan dan tujuan organisasi dapat dicapai secara efektif dan efisien. Selain itu hubungan dan komunikasi atasan dengan karyawan pun harus berjalan dengan harmonis.

Hal tersebut sama kaitannya dengan yang di kemukakan oleh (Siagian, 1998) tentang Human Relations bahwa keseluruhan hubugan, baik yang bersifat formal antara atasan dengan bawahan, atasan dengan atasan serta bawahan dengan bawahan yang lain harus dibina dan dipelihara sedemikian rupa hingga tercipta suatu teamwork dan suasana kerja yang intim dan harmonis dalam rangka pencapaian tujuan.

Berdasarkan hasil frekuensi distribusi pada pernyataan kebijakan dan kedisiplinan pegawai yang di berikan atasan sudah cukup baik yaitu 43 orang (74.1\%) menyatakan setuju. Sedangkan pada pertanyaan tentang atasan bersedia mendengarkan masalah-masalah yang berkaitan dengan pekerjaan sebagian besar menyatakan setuju yaitu 29 orang $(50,0 \%)$ namun pada pernyataan sangat setuju juga cukup banyak dan perlu diperhatikan karena hal tersebut menunjukkan bahwa karyawan menginginkan adanya perhatian dari atasan atas keluhan-keluhan masalah yang berkaitan dengan pekerjaan mereka.

Selanjutnya untuk atasan harus bersedia membantu jika karyawan mengalami kesulitan dalam menyelesaikan tugas, 35 orang $(60,3 \%)$ menyatakan setuju dan 22 orang $(37,95)$ menyatakan sangat setuju sisanya 1 orang $(1,7 \%)$ menyatakan sangat tidak setuju. Berdasarkan uji regresi di 
dapat bahwa kepuasan kerja terhadap atasan memiliki pengaruh yang signifikan yaitu $0,000<0.05$.

Kepuasan Kerja Berdasarkan Rekan Kerja Terhadap Kinerja Karyawan Bagian Manajemen di RSUD Bhakti Dharma Husada Surabaya Tahun 2016

Hubungan kerja antar karyawan sangat diperlukan dalam melakukan pekerjaan terutama bagi karyawan yang bekerja secara berkelompok, apabila terjadi konflik yang timbul dapat memperkeruh suasana kerja dan menurunkan semangat kerja karyawan. Hubungan kerja yang tidak baik terungkap dalam gejala-gejala adanya kepercayaan yang rendah, dan minat yang rendah dalam pemecahan masalah dalam organisasi.

Ketidak percayaan secara positif berhubungan dengan komunikasi antar pribadi pekerja dan ketegangan psikologikal dalam bentuk kepuasan pekerjaan yang rendah, penurunan dari kondisi kesehatan dan rasa diancam oleh Atasan dan rekan-rekan kerjanya, serta berdampak pada komitmen individu dalam suatu organisasi (Munandar, 2001). Oleh karena itu hubungan dan komunikasi yang baik dan harmonis antar rekan kerja sangatlah penting untuk keberlangsungan produktifitass kerja karyawan.

Berdasarkan hasil distribusi frekuensi, pada pernyataan rekan kerja harus saling membantu dalam mengatasi kesulitan menyelesaikan tugas pekerjaan sudah cukup baik yaitu 33 orang (56.9\%) menyatakan setuju. Namun pada hubungan dan komunikasi dengan rekan kerja terjalin dengan baik dan rekan kerja bertanggung jawab atas hasil pekerjaannnya yang menyatakan tidak setuju cukup banyak, hal tersebut perlu menjadi perhatian sesuai dengan ulasan di atas karena hal tersebut dapat terjadi karena adanya konflik antar antar rekan kerja atau kurangnya komunikasi sehingga hubungan yang harmonis pun tidak tercapai. Jika masalah tersebut terus terjadi maka berpengaruh terhadap produktifitas kerja karyawan.
Berdasarkan penelitian uji regresi kepuasan rekan kerja terhadap kinerja memperoleh signifikan $0,653>0.05$ hal tersebut menunjukkan bahwa kepuasan terhadap rekan kerja tidak berpengaruh signifikan terhadap kinerja.

\section{Kepuasan Kerja Berdasarkan Promosi Terhadap Kinerja Karyawan Bagian Manajemen di RSUD Bhakti Dharma Husada Surabaya Tahun 2016}

Promosi merupakan kesempatan untuk berkembang dan maju yang dapat mendorong karyawan untuk lebih baik atau lebih bersemangat dalam melakukan suatu pekerjaan dalam lingkungan organisasi. Dengan adanya promosi, pasti karyawan akan merasa dihargai, diperhatikan, dibutuhkan dan diakui kemampuan kerjanya oleh manajemen sehingga mereka akan menghasilkan outputyang tinggi serta akan mempertinggi loyalitas.

Berdasarkan penelitian uji regresi kepuasan promosi mempunyai pengaruh yang signifikan terhadap kinerja yaitu $0,000<0,05$. Berdasarkan (Robbins, 2001) menyatakan bahwa promosi akan memberikan kesempatan untuk pertumbuhan pribadi, tanggung jawab yang lebih banyak, dan status sosial yang meningkat. Apabila promosi dibuat dengan cara yang adil diharapkan mampu memberikan kepuasan kepada karyawan. Sedangkan Menurut Luthans (2006) menyatakan bahwa "Kesempatan promosimengakibatkan pengaruh yang berbeda terhadap kepuasan kerja karena adanya perbedaan balas jasa yang diberikan".

Hasil penelitian ini sesuai dengan penelitian Simanjuntak (2015) promosi jabatan berpengaruh positif dan signifikan terhadap Kinerja Karyawan pada PT. Riau Media Grafika/ Tribun Pekanbaru.

Kepuasan Kerja Berdasarkan Gaji Terhadap Kinerja Karyawan Bagian Manajemen di RSUD Bhakti Dharma Husada Surabaya Tahun 2016 
Pada prinsipnya gaji merupakan hak yang harus diterima oleh karyawan. Kepuasan gaji yang diterima pada dasarnya tergantung dari persepsi karyawan. Kompensasi yang diterima karyawan sesuai atau bahkan melebihi apa yang dipersepsikannya akan menimbulkan rasa puas pada diri karyawan, sehingga karyawan akan meningkatkan kinerja yang telah dicapainya saat ini (Sunyoto, 2012).

Berdasarkan hasil analisa dari 3 faktor yang ditentukan pada pernyataan gaji yang diterima sudah sesuai dengan beban kerja, yang menyatakan tidak setuju cukup banyak begitu pula dengan pertanyaan gaji yang diterima sudah cukup memenuhi kebutuhan hidup kelurga. Hal tersebut menunjukkan bahwa karyawan merasa kurang puas.

Bila gaji dilihat sebagai adil yang didasarkan pada tuntutan pekerjaan, tingkat ketrampilan individu, dan standar pengupahan komunitas, kemungkinan besar akan dihasilkan kepuasan". Semakin tinggi tingkat pendidikan karyawan, maka semakin tinggi pula tingkat kemungkinan karyawan tersebut melakukan perbandingan sosial dengan karyawan bandingan yang sama di luar perusahaan. Jika gaji yang diberikan perusahaan lebih rendah dibandingkan dengan gaji yang berlakudi perusahaan yang sejenis dan memiliki tipe yang sama, maka akan timbul ketidakpuasan kerja karyawan terhadap gaji. Oleh karena itu gaji harus ditentukan sedemikian rupa agar kedua belah pihak (karyawan dan perusahaan) merasa sama-sama diuntungkan.

Karenakaryawan yang merasa puas dengan gaji yang diterimanya, maka dapat menciptakan kepuasan kerja yang diharapkan berpengaruh pada kinerjakaryawan.Begitu pula Menurut (Handoko, 2001), yang menyatakan bahwa "Ketidakpuasan sebagai besar karyawan terhadap besarnya kompensasi sering diakibatkan adanya perasaan tidak diperlakukan dengan adil dan layak dalam pembayaran mereka". Pendapat serupa dikemukakan (Hasibuan, 2001) bahwa dengan balas jasa atau kompensasi, karyawan akan dapat memenuhi kebutuhan-kebutuhan fisik, status sosial, dan egoistiknya sehingga memperoleh kepuasan kerja dari jabatannya. Namun pada RSUD Bhakti Dharma Husada Surabaya berdasarkan uji regresi menunjukkan bahwa kepuasan gaji terhadap kinerja karyawan mempunyai signifikan 0,021 dan $>0,05$ hal tersebut menunjukkan kepuasan terhadap gaji tidak mempunyai pengaruh pengaruh terhadap kinerja. Penelitian Subakti Syaiin (2008) juga menyebutkan variabel kepuasan terhadap gaji ternyata tidak mempunyai pengaruh yang signifikan terhadap kinerja pegawai.

\section{Kinerja Karyawan Bagian Manajemen Rumah Sakit di RSUD Bhakti Dharma Husada Surabaya Tahun 2016}

Berdasarkan hasil analisis kinerja karyawan yang terdiri dari 7 pernyataan pada kuesioner menunjukkan cukup baik. Namun pada tingkat kehadiran $100 \%$ per bulan yang menyatakan tidak setuju cukup banyak di bandingkan dengan pernyataan lainnya. Tingkat kehadiran tersebut berhubungan dengan kedisiplinan. Rendahnya tingkat disiplin kerja pegawai sering kali dikeluhkan oleh berbagai pihak karena menyebabkan rendahnya kualitas pelayanan yang mereka dapatkan. Hal tersebut perlu menjadi perhatian untuk menyadarkan pegawai tentang kedisiplinan pegawai, karena jika dibiarkan akan menimbulkan dampak buruk. Salah satu cara mengatasi faktor penghambat dalam peningkatan disiplin kerja pegawai adalah pendekatan yang dilakukan oleh seorang pimpinan, dimana pimpinan dapat menjelankan fungsi kepemimpinannya agar para pegawai tidak lagi melanggar aturan-aturan atau ketentuan-ketentuan yang telah dibuat dan disepakati. Selan itu juga hendaknya para pegawai dapat meningkatkan lagi disiplinnya dengan tujuan memperoleh prestasi yang lebih tinggi lagi di kantor. Usaha dalam mengatasi ketidakdisiplinan pegawai 
tersebut dapat dilakukan oleh pimpinan dengan menjalankan fungsi kepemimpinannya.

\section{KESIMPULAN}

1. Hasil identifikasi kepuasan kerja karyawan bagian manajemen di RSUD Bhakti Dharma Husada Surabaya dilihat dari 5 dimensi spesifik yaitu: pekerjaan itu sendiri, atasan, teman kerja, promosi, dan gaji menunjukkan tingkat kepuasan yang bervariasi yaitu:

a. Kepuasan terhadap pekerjaan menunjukkan kurang baik pada sarana dan prasarana ATK, hal tersebut di tunjukkan pada presentase $50 \%$ dari responden menyatakan tidak setuju bahwa ATK sudah memadai.

b. Kepuasan terhadap atasan menunjukkan kurang baik pada kebijakan dan kedisiplinan yang diberikan kepada pegawai, dari 58 responden terdapat responden yang menjawab tidak setuju yaitu sebesar $12,1 \%$, jika dibandingkan dengan presentase lainnya persentase tersebut paling dominan.

c. Kepuasan terhadap rekan kerja ada dua pertanyaan yang hasilnya menunjukkan responden tidak setuju dan presentasenya dominan dibandingkan dengan lainnya, yaitu pada komunikasi yang terjalin baik dan rekan kerja sudah bertanggungjawab terhadap hasil pekerjaannya

d. Kepuasan terhadap promosi mununjukkan kurang baik hal tersebut ditunjukkan pada pertanyaan bahwa prestasi kerja memungkinkan mendapat peluang promosi jabatan responden menyatakan tidak setuju cukup banyak dibandingkan lannya bahkan ada yang menyatakan sangat tidak setuju.

e. Kepuasan terhadap gaji menunjukkan kurang baik hal tersebut di tunjukkan dari 3 pertanyaan semua pertanyaan menggambarkan presentase responden yang menyatakan sangat tidak setuju cukup banyak.

2. Hasil identifikasi kinerja karyawan di bagian manajemen di RSUD Bhakti Dharma Husada Surabaya dari tujuh pertanyaan, pada tingkat kehadiran harus $100 \%$ per bulan cukup banyak responden yang menyatakan tidak setuju yaitu 18 orang (31\%). Hal tersebut dapat terjadi pada keadaan dimana karyawan sakit dan tidak memungkinkan untuk bekerja sehingga izin kerja, sehingga tingkat kehadirannya menjadi berkurang.

3. Hasil analisis pengaruh kepuasan kerja terhadap kinerja karyawan bagian manajemen di RSUD Bhakti Dharma Husada Surabaya, dari lima dimensi kepuasan ada dua dimensi yang berpengaruh terhadap kinerja karyawan yaitu pada atasan dan promosi. Sedangkan pada dimensi pekerjaan, gaji dan rekan kerja tidak memiliki pengaruh yang signifikan, hal tersebut dapat terjadi karena kurang mengungkapkan faktor lainnya dalam mengukur kinerja karyawan, sehingga menyebabkan 3 dimensi tersebut tidak memiliki signifikan.

\section{SARAN}

Berdasarkan hasil penelitian dan dari kesimpulan maka peneliti menyarankan:

1. Saran Untuk Rumah Sakit:

a. Meningkatkan pengadaan sarana prasarana ATK namun dengan tetap memperhatikan efisiensi anggaran yaitu dengann memenuhi ATK karyawan yang sesuai dengan tugas, jabatan dan kebutuhan.

b. Pembuatan kebijakan mengenai promosi jabatan oleh direktur rumah sakit atau pemberian reward kepada karyawan yang kinerjanya baik. Sehingga karyawan akhirnya memiliki rasa tanggungjawab untuk memberikan yang terbaik untuk 
rumah sakit dan meningkatkan produktifitas kerjanya.

c. Menjalankan hubungan komunikasi yang baik dengan karyawan dan mendengarkan masalah-masalah yang berkaitan dengan pekerjaan, Sebagai masukan dapat dilakukan pertemuan dengan atasan secara periodik atau dengan dilakukan briefinguntuk membicarakan masalah-masalah yang berkaitan dengan pekerjaan.

2. Saran Bagi Peneliti Lain

a. Penelitian selanjutnya sebaiknya menambah variabel yang lain agar didapatkan hasil lebih akurat mengenai variabel-variabel apa saja yang mempengaruhi kepuasan kerja ataupun kinerja.

b. Penelitian selanjutnya sebaiknya memperluas ruang lingkup penelitian tidak hanya karyawan di bagian manajemen namun seluruh karyawan di RSUD Bhakti Dharma Husada Surabaya.

\section{DAFTAR PUSTAKA}

Depkes RI. 2013. Riset Kesehatan Dasar. Jakarta: Badan Penelitian dan pengembangan Kesehatan Kementrian Kesehatan RI.

Fahmi, Irham, 2013. Manajemen Pengambilan Keputusan Teori dan Aplikasi. Bandung: Alfabeta.

Gouzali, Saydam, 2000.Manajemen Sumber Daya Manusia (Human Resource) Suatu Pendekatan Mikro. Jakarta: Djanbatan.

Handoko, T. Hani. 2001. Manajemen Personalia dan Sumberdaya Manusia, Edisi Kedua, BPFE, Yogyakarta.

Hasibuan, SP., 2000. Manajemen Sumber Daya Manusia, STIE YKPN, Yogyakarta.

Luthans, F., 2006. Perilaku Organisasi Edisi Sepuluh. Yogyakarta: Andi.

Mangkunegara, Anwar Prabu 2006. Evaluasi Kinerja Sumber Daya Manusia. Jakarta: Refika Aditama.
Munandar, M., 2001. Budgeting, Perencanaan Kerja Pengkoodinasian Kerja Pengawasan Kerja.Edisi Pertama. Yogyakarta: Universitas Gajah Mada.

Robbins, Stephen P., 2001. Perilaku Organisasi, PT Indeks, Kelompok Gramedia, Jakarta.

Siagian, S., 1998. Manajemen Sumber Daya Manusia. Jakarta: Bumi Aksara.

Simajuntak, W., 2015. Pengaruh Promosi Jabatan Pada PT. Riau Medika Grafika/ Tribun Pekan Baru. Skripsi.Riau. Universitas Riau.

Sunyoto, D., 2012. Manajemen Sumber Daya Manusia. Yogyakarta: CAPS

Syaiin, Subakti, 2007. Pengaruh Kepuasan Kerja Terhadap Kinerja Pegawai Klinik Spesialis Bestari Medan. Skripsi. Medan. Sumatra Utara.

Wibowo. 2014. Manajemen Kinerja. Jakarta: Raja Grafindo Persada.

Wulan. 2011. Analisis Pengaruh Motivasi Kerja dan Lingkungan Kerja terhadap Kinerja Karyawan. Skripsi. Semarang, Universitas Diponegoro. 